\title{
Assessment of Technological Knowledge on Pre- and Post-harvest Agricultural Management System and its Economic Impacts in Bangladesh
}

\author{
Mohammad Amir Hossain Mollah ${ }^{1}$, Abdul Jabber Hawlader ${ }^{2}$ Md. Razzab Ali ${ }^{3}$, Razia Khatun ${ }^{4}$, \\ Shamim Ahmed ${ }^{4}$, Mohammad Showkat Mahmud ${ }^{4}$, Md. Amirul Hasan,"* \\ ${ }^{1}$ Development Technical Consultants Pvt. Ltd. Dhaka, Bangladesh \\ ${ }^{2}$ Department of Zoology, Jahangirnagar University, Savar, Dhaka, Bangladesh \\ ${ }^{3}$ Department of Entomology, Sher-e-Bangla Agricultural University, Dhaka, Bangladesh \\ ${ }^{4}$ Bangladesh Livestock Research Institute, Savar, Dhaka, Bangladesh
}

Copyright $\subseteq 2018$ by authors, all rights reserved. Authors agree that this article remains permanently open access under the terms of the Creative Commons Attribution License 4.0 International License

\begin{abstract}
The field survey was conducted among the farmers, researchers, extensionist and agribusiness personnel to assess their knowledge about National Agricultural Research System (NARS) recommended technologies on pre- and post-harvest management and their economic impact in Bangladesh. The survey was conducted in 16 Upazilas (2 Upazilas from each district) of purposively selected eight (8) districts based on agricultural project activities on potential of major crop groups and system through a standard pre-tested questionnaire. From the field survey, it revealed that only a few number of technologies were available at field level regarding pre and post-harvest management out of more than 300 NARS recommended technologies. There was also found a big knowledge gap among farmers; researchers and other respondents. Considering all technological categories, perceptions of researchers on NARS recommended technological knowledge were found much higher than farmers, extensionist and agribusiness personnel. There was also a big Knowledge gap between project intervention districts than less or zero project intervention Districts. It was also observed that most of the respondents were very much aware about the rice based technologies rather than other crops, especially most of the small scale poor farmers were interested to use cheap, easy handling and locally available technology for their crop regarding pre and post management at field level.
\end{abstract}

Keywords Technological Knowledge, Pre- and Post-harvest, Agricultural Pest, Economic Impact, Bangladesh

\section{Introduction}

Agriculture plays a key role in the overall economic performance of Bangladesh, in terms of its contribution to GDP, as a major source of foreign exchange earnings, and in providing employment to about $65 \%$ of the country's population. Moreover, the livelihoods of $75.40 \%$ of the rural population in Bangladesh are still dependent on agriculture. Agricultural research and development in Bangladesh has contributed tremendously to meeting the food requirements of Bangladesh's population of approximately 160 million. Rice is the staple cereal crop of Bangladesh, $75 \%$ of agricultural land use and more than $50 \%$ household are involve in rice production system. Major cereal crops in Bangladesh are rice and wheat. The production of total food grain in the FY 2012-13 was 35.10 MMT and wheat 1.26 MMT) [8]. The contribution of vegetables remains extremely important for ensuring food and nutritional security in Bangladesh. Horticultural crops in Bangladesh cover an area of 873 thousand hectares with a total production of 11 million metric tons [9]. Due to tropical and subtropical climates, a variety of fruits and vegetables are grown in Bangladesh. Unfortunately, a considerable proportion of the harvested produce never reaches the consumers mainly because of postharvest losses. The estimated postharvest losses of fruits and vegetables lie in the range of $20-40 \%$ [36]. Hence, there is general support among scientists for the proposition that increased returns to growers and other stakeholders in the supply chain might come from proper management after harvest rather a further boost to crop production in the field. The principal reasons for postharvest losses are: (i) physiological and biochemical processes i.e. increase in the rates of respiration, ethylene production and transpiration 
loss of water, (ii) microbial decay, (iii) high perish ability, and (iv) sub-standard postharvest handling infrastructures.

Post-harvest sector includes all points in the value chain from production in the field to the food being placed on a plate for consumption. It includes harvesting, handling, storage, processing, transportation and marketing. The amount of resources used and the efficiency of production depend upon the use of appropriate technologies, infrastructure, processing, marketing and transportation [7].The postharvest quality of fruits and vegetables are largely determined by pre-harvest factors such as production location, soil type, irrigation, rootstock, shading and nutrition.[23] The post-harvest factors divided into primary and secondary. The primary factors include climate, nutrition and plant growth regulators, and the secondary factors include soil quality and management, rootstock, irrigation, pruning and crop load manipulation. Postharvest management is a set of post-production practices that includes: cleaning, washing, selection, grading, disinfection, drying, packing and storage. These eliminate undesirable elements and improve product appearance, as well as ensuring that the product complies with established quality standards for fresh and processed products. Postharvest practices include the management and control of variables such as temperature and relative humidity, the selection and use of packaging, and the application of such supplementary treatments as fungicides [13]. In India, different types of improved postharvest management practices have been introduced. For example, improved fruit pack house and vegetables packaging with modified atmosphere technologies are in used [11]. In Bangladesh cases the situation of postharvest management of horticultural commodities is still sub-standard. Immediate intervention is needed to improve the present status of postharvest management so that the losses are minimized, and quality and safety standards are maintained. The aim of postharvest management is to maximize this added value. This ultimately should benefit the whole community, whether through increased export earnings or extending the availability of fresh produce through the year. Conversely losses hurt everyone. Kader A.A [20] has estimated that from 5 to $25 \%$ of fruit and vegetables leaving the farm gate is never consumed, but has to be thrown away.

There is no official information in Bangladesh regarding extend of post-harvest losses in vegetables due to lack of technological knowledge. Knowledge about the present post-harvest activities was found to be practiced at a very limited level [1]. Usually sun-dried and wind dried operations are very common for agricultural produces and sorting and grading are practiced before marketing following the indigenous technology. Traders generally do pack house operation. Although a number of training programs are being organized by DAE and other organizations including NGOs, these are mostly on production oriented and training on post-harvest management and marketing techniques are scarce. The fruits and vegetables production are often excess of the local demand and the surplus could be meaningfully utilized by careful post-harvest management of the produces. It was observed that a substantial portion of the harvest is wasted in the region annually due to improper harvesting and post-harvest practices, diseases, lack of facilities and technology to extend their storage life, which cause heavy losses in revenue to the growers, wholesalers, retailers, exporters and inconvenience to the consumers and lowers export potential of these commodities. However, in developed countries losses in post harvest chain are generally small during processing, handling and storage because of availability and affordability of advanced technology, strictness in management of variables that may lead into losses and the high- quality standards set by retailers. [17,29]. In developing countries post-harvest, losses are higher since most of the countries are characterized by lack or the use of old or poor equipment and lack of skilled managers for assisting in losses reduction in the food sector properly [17]. Postharvest losses in food grains in Bangladesh are reported at an estimated $15 \%$, while in fruits and vegetables they are estimated at $20-25 \%$. For highly perishable fruits and vegetables, these losses may go as high as $40 \%$. The problem of postharvest losses is compounded by the lack of proper processing, preservation and storage systems. The absence of a well-developed marketing network and rapid transportation in the country also contributes significantly to high post-harvest losses in fruits and vegetables. Presently some scattered studies have been initiated to assess crop losses, particularly on rice. However, no systematic and scientific approach has yet been taken to assess these losses on different crops over a period of time. The estimated postharvest losses of fruits and vegetables as reported from overseas are $15-50 \%$ [27] and $20-40 \%$ [37]). The estimates of postharvest losses of banana, citrus and papaya were $20-80 \%, 20-95 \%$ and 40-100\%, respectively [25]. Paull, R.E. [28] speculated that sometimes these figures are guesses, and in many cases may be colored by isolated incidents. For instance in mango, postharvest losses were 0-16.3\% [32], 30-35\% [24] and $27.2 \%$ [5]. Postharvest losses of fruits and vegetables were $25-50$ and $25-40 \%$ as reported by [ 4 ] respectively. So, there is no doubt that enormous amounts of fruits and vegetables are lost every year. Most of the data available are based mainly on experiments conducted at different research stations and Universities. Most of the data on crop losses have been derived from indirect sources. In most cases, accuracy of yield reduction estimates was limited due to the quantity and quality of data available. That is why it has been a difficult task to compile reliable annual crop loss estimation for any crops. The problems recorded in the application of post-harvest practices are: lack of adequate knowledge, space for assembling, sorting, grading and packaging; poor post-harvest technology, 
inadequate transportation and lack of storage facility/processing center. The farmers are practicing post-harvest activities with traditional knowledge of simple sorting and grading or washing the produces. They have very little post-harvest management knowledge and have no exposure on modern post-harvest technologies of High Value Crops (HVCs). They urged that they could not find any additional benefit of doing sorting, grading and washing or cooling of their produces. They informed that it is costly and time consuming and does not attract the interest of the traders. The economic impact of post-harvest research investments is encouraging, and does not warrant a continued discrimination against such activities in funding allocations. Researchers [5] pointed out that post-harvest research contributes to food security and health in several ways. Improved storage technologies, such as biological pest control or controlled atmosphere storage reduce post-harvest food losses. Reducing losses increases the amount of food available for consumption. Postharvest management is pivotal in an agricultural country such as Bangladesh. Success in agricultural production and in marketing hinges upon proper postharvest handling, storage, and processing of cereals, oil seeds, legumes and horticultural crops. Current postharvest handling of these crops, however, presents an opposite picture. Traditional techniques which result in considerable deterioration of physical and nutritional quality are generally practiced by growers, traders and processors. Improvement of these age-old practices and development of new technologies through organized research and development efforts have now become essential in order to reduce the tremendous levels of postharvest losses in grains, and fruits and vegetables, so as to increase the supply for food from a limited land resource area and thereby strengthen the economy of the country.

In view of the above facts the study was conducted with the critical analysis of the existing technological knowledge and level of adoption of pre and post-harvest agricultural management practices of crops, to identify the gaps between existing agricultural pre and post harvest management system and expectations from the perspective of stakeholders and to recommend the output of the study to the concerned policy makers of Government.

\section{Materials and Methods}

\section{Location of the Study}

Field survey was conducted in the eight (8) districts (Bogra, Pabna, Nilphamari, Gaibandha, Kurigram, Dinajpur, Panchagar and Netrakona) of Bangladesh and it was purposively selected based on agricultural project activities, potential of major crop groups and potential system. The control district was purposively selected based on zero projects activities, and single crop potential. The field data were collected from four categories of respondents such as Farmers-who has land of more than one crops, Extensionists, Researches, and Agribusiness men following face to face interviews.

\section{Development of the Questionnaire and Collection of Data}

The main instrument for the data collection was structured questionnaires. The questionnaire was pre-tested in the sample location and finalized with due care to the objectives of the research work as well as the consistency with the scope of work. Direct personal interview approach was applied for collection of respective data. Necessary data were collected based on questionnaire guideline and checklist of the questionnaire following the standard.

\section{Sampling}

The total 480 number respondents were interviewed where 320 farmers, 48 Researcher, 64 Extensionist, 48 Agri-businessmen covered under in eight districts of Bangladesh. In addition, eight FGDs (Focus Group Discussions) and some Key Informant Interviews (KII) were also administered with different stakeholders.

\section{Data Analysis}

The well filled-in questionnaires were considered as the source of raw data for effective and accurate analysis and finally as a whole quality output generation. All the necessary data was analyzed using Excel and SPSS computer software. For the analysis of the studied data, descriptive statistics such as percent, sum and average etc was used to describe some characteristics.

\section{Results and Discussion}

Interviews were conducted in 16 randomly selected Upazilas of 8 districts in Bangladesh. Out of 300 NARS (National Agricultural Research System) recommended technologies, so far 36 technologies were found to cover the pest management, post-harvest and agribusiness categories.

\section{a) Farmer's Knowledge on Technology}

The results of crop wise available technological knowledge including their major categories and sub-categories have been discussed under the following sub-headings:

\section{Technological Knowledge}

The technological knowledge encompasses ideas the technology, attaining perception for the technology and to practically working or adopting skills about the technology, the data were collected on the above three categories of technological aspects for 4 major crops group cases and are given in the Table 1. 
Table1. Farmers' perception of technological knowledge on pre and post-harvest agricultural pests and their economic impacts in Bangladesh

\begin{tabular}{|c|c|c|c|c|c|c|c|c|c|c|}
\hline \multirow{3}{*}{$\begin{array}{c}\text { Technological } \\
\text { Category }\end{array}$} & \multicolumn{10}{|c|}{ Crop wise Technological knowledge } \\
\hline & \multicolumn{2}{|c|}{ Cereal } & \multicolumn{2}{|c|}{ Vegetable/fruit } & \multicolumn{2}{|r|}{ Pulse } & \multicolumn{2}{|r|}{ Spices } & \multicolumn{2}{|r|}{ Total } \\
\hline & $\begin{array}{c}\text { *NARS } \\
\text { Tech. (No.) }\end{array}$ & Response (\%) & $\begin{array}{l}\text { NARS } \\
\text { Tech. } \\
\text { (No.) }\end{array}$ & $\begin{array}{l}\text { Response } \\
(\%)\end{array}$ & $\begin{array}{l}\text { NARS } \\
\text { Tech. } \\
\text { (No.) }\end{array}$ & Response $(\%)$ & $\begin{array}{l}\text { NARS } \\
\text { Tech. } \\
\text { (No.) }\end{array}$ & Response (\%) & $\begin{array}{l}\text { NARS } \\
\text { Tech. } \\
\text { (No.) }\end{array}$ & Response (\%) \\
\hline \multicolumn{11}{|c|}{ 1. Technological Knowledge } \\
\hline Ideas & 22 & $29.68(6.53)$ & 28 & $17.46(4.89)$ & 14 & $22.29(3.12)$ & 11 & $26.18(2.88)$ & 75 & $23.25(17.44)$ \\
\hline Perception & 22 & $28.14(6.19)$ & 28 & $16.32(4.57)$ & 14 & 21.93(3.07) & 11 & $25.27(2.78)$ & 75 & $22.15(16.61)$ \\
\hline Skills & 22 & $23.00(5.06)$ & 28 & $12.64(3.54)$ & 14 & $14.93(2.09)$ & 11 & $19.82(2.18)$ & 75 & $17.16(12.87)$ \\
\hline \multicolumn{11}{|c|}{ 2. Post Harvest Activities } \\
\hline Harvest index & 9 & $43.42(5.48)$ & 9 & $52.88(2.85)$ & 9 & $45.26(2.29)$ & 9 & $56.87(2.65)$ & 36 & $47.82(13.27)$ \\
\hline $\begin{array}{l}\text { Accompanying } \\
\text { pest at harvest }\end{array}$ & 9 & $16.88(2.13)$ & 7 & $14.29(0.77)$ & 7 & $21.15(1.07)$ & 7 & $19.96(0.93)$ & 30 & $17.59(4.88)$ \\
\hline $\begin{array}{l}\text { Post-harvest } \\
\text { processing }\end{array}$ & 12 & $39.70(5.01)$ & 6 & $32.65(1.76)$ & 3 & $33.60(1.70)$ & 3 & $23.82(1.11)$ & 24 & $21.01(5.83)$ \\
\hline Marketing & 9 & $27.03(1.83)$ & 9 & $32.39(2.18)$ & 9 & 40.34 (1.44) & 9 & $40.72(0.79)$ & 36 & $32.86(6.25)$ \\
\hline
\end{tabular}

The number within the parenthesis indicates the number of technologies being responded by the farmer. *The number of NARS recognized available technologies

The results depicted in (Table1) where significant variations noticed among different crop categories in relation to the farmer's perception on the NARS recognized technological knowledge/activities available in the field. In case of cereal crops, there were significant variations among three technological knowledge viz. ideas, perception, and skills of improved technology and the technological knowledge was ranged from $23 \%$ (5.06) to $29.68 \%$ (6.53). More or less similar trends were found for vegetables/fruits $12.64 \%$ (3.54) to $17.46 \%$ (4.89) for pulse $14.93 \%$ (2.09) to $22.29 \%$ (3.12) and for spices $19.82 \%$ (2.18) to $26.18 \%$ (2.88). Considering the four crop categories, the highest number of technologies part found $29.68 \%, 28.14 \%$, and $23.00 \%$ in ideas, perception, and skills respectively. There were significant differences among ideas, perception, and skills of improved technology. Few works had been done on the technological knowledge of pre and post-harvest agricultural management and their economic impacts in Bangladesh. This result supported by [5] that while research on the improvement of agricultural production has received considerable attention and funding but until today post-harvest activities especially on spices have not attracted much attention from national and international research organizations. It also supported by [13] finding that the production technologies currently available for cereal crops grown by smallholder farmers farming under rain-fed conditions in the semi-arid regions of southern Africa. In this connection [19] studied to determine the farmers' knowledge on post harvest practices of vegetables and explore the contribution of the selected characteristics of the vegetable growers on their knowledge on postharvest practices of vegetables using 109 vegetable growers of six villages of Belgachi Union of Alamdanga Upazila under Chuadanga district found majority of the respondents (56 percent) had medium knowledge on post harvest practices of vegetables, while 8.3 percent had low knowledge and
35.8 percent had high knowledge. Hence, more than half (64.30 percent) of vegetable growers had low to medium knowledge on postharvest practices of selected vegetables. Stepwise multiple regressions exposed that adoption of postharvest practices, problem faced in vegetable cultivation, experience in vegetable cultivation, training exposure on vegetable cultivation, level of education had significant contribution on their knowledge on post-harvest practices of vegetables. Farmers faced higher problems in 'lower price of vegetables' followed by 'high price of inputs' and 'disease attack'.

\section{Post-harvest Activities}

The results depicted in (Table 1) found significant variations in the perceptions of farmer's on the NARS recognized technologies/activities regarding post-harvest activities viz. harvest index, accompanying pest at harvest and post-harvest processing available in the field of different crops. In case of cereal crops, the number of known post-harvest activities ranged from $16.88 \%-43.42 \%$, where the highest number of activities were observed in respect of harvest index and the lowest number of activities were observed in respect of accompanying pest at harvest. In case of vegetables/fruits sub-sector, the number of known post-harvest activities ranged from $14.29 \%-52.88 \%$ out of $9,7, \& 6$ activities, where the highest number of activities was observed in respect of harvest index and the lowest number of activities was observed in respect of pests accompanying at harvest. More or less similar trends of results in case of pulse $(21.15 \%-45.26 \%$ out of $9,7 \& 3$ activities) and spices $(19.96 \%-56.87 \%$ out of $9,7, \& 3$ activities). Sharp and significant variations were observed among three categories of post-harvest respectively in respect of all categories of crops. The research team [1] stated that Post-harvest activities in Bangladesh are traditional and labour intensive. The main activities are manual harvesting, manual threshing, animal or 
mechanical treading, sun drying, traditional parboiling and milling in huller mills or traditional devices. Processing losses are very high, due mainly to traditional processing methods and use of inefficient machinery. It is concluded that the rubber roll huller should be used in Bangladesh for better milling output and quality of rice.[34] conducted a research on the influence of farm practices attributes on innovation decision process by the farmers of Dharmapuri district in Tamilnadu, India. They found that profitability was significantly correlated with the adoption of recommended farm practices. They defined profitability as the amount of production cost compared with sold cost. So, profitability as use by them is synonymous with the commercialization of the present study. [2] conducted a study on the adoption of modern T. Aman technologies among the rice growers in Sadar Thana of Rangpur District. He found that commercialization of the farmers had no significant and positive relationship with their adoption of modern T. Aman technologies.

\section{B) Extensionists' Knowledge on Technology}

The results of crop wise available technological knowledge of agricultural extensionist including their major categories and sub-categories have been discussed under the following sub-headings:

\section{Technological Knowledge}

The results depicted in (Table 2) observed significant variations among different crop categories in relation to the extensionist's perception on the NARS recognized technological knowledge/activities available in the field. In case of cereal crops, the number of known technological knowledge ranged from 35.91\% (7.90) - 43.41\% (9.55), but there were significant variations irrespective of technological knowledge viz. ideas, perception, and skills of improved technology. More or less similar trends were found in case of vegetables/fruits $26.79 \%(7.50)-32.36 \%$ (9.06) out of 28 technologies, pulse $22.64 \%$ (3.17) $37.00 \%$ (5.18) out of 14 technologies and spices $24.91 \%$ (2.74) $-41.64 \%$ (4.58) out of 11 technologies. Considering the four crop categories, the highest number of technologies 9.55, 9.49 and 7.90 in ideas, perception, and skills, respectively were perceived by the extensionists' in cereal crop followed by vegetables/fruits $9.06,8.50$ and 7.50 pulse $5.18,4.95$ and 3.17 and spices $4.58,4.49$ and 2.74 , respectively. But the sharp variations found $37.83 \%$, $36.57 \%$, and $21.31 \%$ technologies out of 75 among different levels of technological item in respect of total number of crops. This results are in agreement of [14] and [36] statement on the extensioists technological knowledge. [18] found that training on vegetable cultivation had a positive and substantial significant relationship with knowledge on vegetables production activities by woman members in homestead area under world vision project. [15] found that the length of the training of the respondents had positive relationship with their knowledge of crop cultivation. [34] in his study found that the training received by the farmers had a positive significant relationship with their knowledge on food and nutrition.

Table 2. Extensionists' perception of technological knowledge on pre and post-harvest management of agricultural pests and their economic impacts in Bangladesh

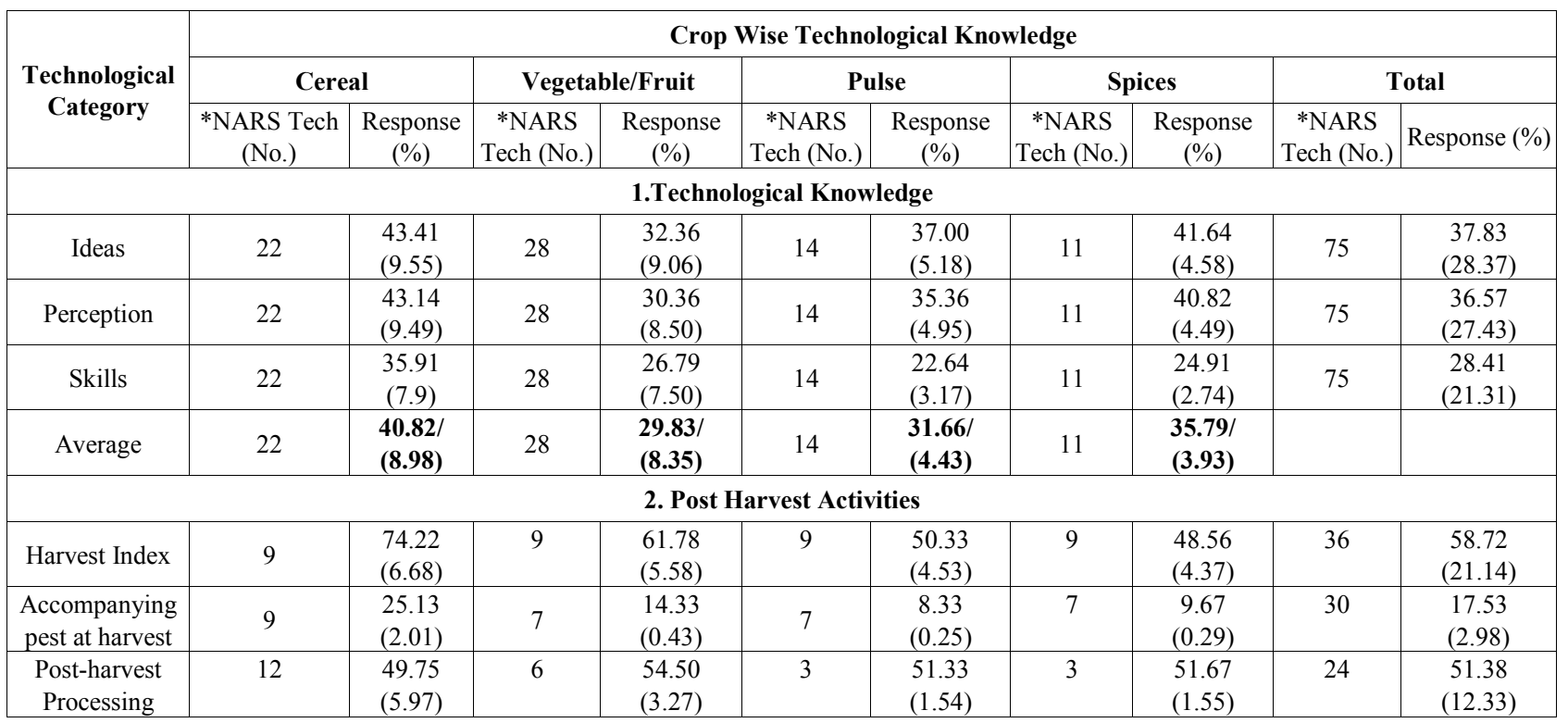

The number within the parenthesis indicates the number of technologies being responded by the farmer. * the number of NARS recognized available technologies 


\section{Post-harvest Activities}

The results depicted in (Table 2) found significant variations in the perceptions of extensionist on the NARS recommended technologies/activities regarding post-harvest activities viz. harvest index, accompanying pest at harvest and post-harvest processing available in the field for different crops. In case of cereal crops the number of known post-harvest activities ranged from $25.13 \%-74.22 \%$,forvegetables/fruits sub-sector ranged from $14.33 \%-61.78 \%$ where the highest number of activities observed in-harvest index and the lowest number observed in accompanying pest at harvest. More or less similar trends observed in pulse $9.67 \%-48.56 \%$ and spices $17.53 \% \quad 0.70-4.45$ respectively. Sharp and significant variations were observed among three categories of post-harvest activities for harvest index, accompanying pest at harvest and post-harvest processing respectively in respect of all type crops. The research groups [3] and [33] also supported the results as stated in the farmers' post-harvest activities.

\section{C) Researcher Knowledge on Technology}

The results of crop wise available technological knowledge of researcher including their major categories and sub-categories have been discussed under the following sub-headings:

\section{Technological Knowledge}

The results depicted in Table 3 found significant variations among different crop categories in relation to the researcher perception on the NARS recognized technological knowledge/activities available in the field. In case of cereal crops, the percent of technological knowledge ranged from 66.73-68.18, but there were no significant variations among three technological knowledge viz. ideas, perception, and skills of improved technology. More or less similar trends were found for vegetables/fruits (57.64-58.57) for pulse (67.71-71.36) and for spices (68.55-69.73) respectively. Considering the four crop categories, the highest number of technologies 15.00 , $14.78,14.68$ in ideas, perception, and skills, respectively were perceived by the researcher in cereal crop; vegetables/fruits16.40, 16.35, and 16.14, for pulse9.99, 9.65, and 9.48, and for spices 7.67, 7.58, and 7.54, respectively. There were no significant variations in respect of ideas, perception and skills of improved technological knowledge. The Researcher [35] found the great potential for income and employment generation in production agriculture and post-harvest operations through the use of appropriate agricultural engineering technology is discussed taking India as an example of a developing country situation.

Table 3. Perception of researchers' technological knowledge on pre and post-harvest pest management system and their impact on agribusiness in Bangladesh

\begin{tabular}{|c|c|c|c|c|c|c|c|c|c|c|}
\hline \multirow{3}{*}{$\begin{array}{l}\text { Technological } \\
\text { Category }\end{array}$} & \multicolumn{10}{|c|}{ Crop Wise Technological Knowledge } \\
\hline & \multicolumn{2}{|c|}{ Cereal } & \multicolumn{2}{|c|}{ Vegetable/Fruit } & \multicolumn{2}{|c|}{ Pulse } & \multicolumn{2}{|c|}{ Spices } & \multicolumn{2}{|c|}{ Total } \\
\hline & $\begin{array}{c}\text { *NARS } \\
\text { Tech (No.) }\end{array}$ & $\begin{array}{c}\text { Response } \\
(\%)\end{array}$ & $\begin{array}{c}\text { *NARS } \\
\text { Tech (No.) }\end{array}$ & Response (\%) & $\begin{array}{c}\text { *NARS } \\
\text { Tech (No.) }\end{array}$ & $\begin{array}{c}\text { Response } \\
(\%)\end{array}$ & $\begin{array}{c}\text { *NARS } \\
\text { Tech (No.) }\end{array}$ & $\begin{array}{c}\text { Response } \\
(\%)\end{array}$ & \begin{tabular}{|c|} 
*NARS \\
Tech (No.) \\
\end{tabular} & $\begin{array}{c}\text { Response } \\
(\%)\end{array}$ \\
\hline \multicolumn{11}{|c|}{ 1.Technological Knowledge } \\
\hline Ideas & 22 & $\begin{array}{c}68.18 \\
(15.00)\end{array}$ & 28 & $\begin{array}{c}58.57 \\
(16.40)\end{array}$ & 14 & $\begin{array}{l}71.36 \\
(9.99) \\
\end{array}$ & 11 & $\begin{array}{l}69.73 \\
(7.67) \\
\end{array}$ & 75 & $\begin{array}{c}65.33 \\
(49.00)\end{array}$ \\
\hline Perception & 22 & $\begin{array}{c}67.18 \\
(14.78)\end{array}$ & 28 & $\begin{array}{c}58.39 \\
(16.35) \\
\end{array}$ & 14 & $\begin{array}{l}68.93 \\
(9.65) \\
\end{array}$ & 11 & $\begin{array}{l}68.91 \\
(7.58)\end{array}$ & 75 & $\begin{array}{c}64.48 \\
(48.36)\end{array}$ \\
\hline Skills & 22 & $\begin{array}{c}66.73 \\
(14.68)\end{array}$ & 28 & $\begin{array}{c}57.64 \\
(16.14) \\
\end{array}$ & 14 & $\begin{array}{l}67.71 \\
(9.48)\end{array}$ & 11 & $\begin{array}{l}68.55 \\
(7.54)\end{array}$ & 75 & $\begin{array}{c}63.79 \\
(47.84) \\
\end{array}$ \\
\hline \multicolumn{11}{|c|}{ 2. Post Harvest Activities } \\
\hline Harvest Index & 9 & $\begin{array}{l}96.22 \\
(8.66) \\
\end{array}$ & 9 & $\begin{array}{l}96.22 \\
(8.66) \\
\end{array}$ & 9 & $\begin{array}{l}95.22 \\
(8.57)\end{array}$ & 9 & $\begin{array}{l}95.22 \\
(8.57)\end{array}$ & 36 & $\begin{array}{c}95.72 \\
(34.46)\end{array}$ \\
\hline $\begin{array}{l}\text { Accompanying } \\
\text { pest at harvest }\end{array}$ & 9 & $\begin{array}{l}55.78 \\
(5.02)\end{array}$ & 7 & $\begin{array}{l}51.71 \\
(3.62)\end{array}$ & 7 & $\begin{array}{l}50.29 \\
(3.52)\end{array}$ & 7 & $\begin{array}{l}48.00 \\
(3.36)\end{array}$ & 30 & $\begin{array}{c}51.73 \\
(15.52)\end{array}$ \\
\hline $\begin{array}{c}\text { Post-harvest } \\
\text { Processing }\end{array}$ & 12 & $\begin{array}{l}80.33 \\
(9.64)\end{array}$ & 6 & $\begin{array}{l}93.00 \\
(5.58)\end{array}$ & 3 & $\begin{array}{l}89.00 \\
(2.67)\end{array}$ & 3 & $\begin{array}{l}88.00 \\
(2.64)\end{array}$ & 24 & $\begin{array}{c}85.54 \\
(20.53)\end{array}$ \\
\hline
\end{tabular}

The number within the parenthesis indicates the number of technologies being responded by the farmer. * the number of NARS recognized available technologies 


\section{D) Agribusiness Personnel Knowledge on Technology}

The results of crop wise available technological knowledge of agribusiness personnel including their major categories and sub-categories have been discussed under the following sub-headings:

\section{Technological Knowledge}

Significant variations among different crop categories were observed in relation to the agribusiness personnel perception on the NARS recognized technological knowledge/activities available in the field (Table 4). In case of cereal crops, the percent of known technological knowledge ranged from 23.41-41.59, but there is a significant variation among three technological knowledge viz. ideas, perception, and skills of improved technology. More or less similar trends were found in vegetables/fruits 21.50-48.29 out of 28 technologies in pulse 20.14-50.93 out of 14 technologies and for spices 25.64-53.45 out of 11 technologies. Considering the four crop categories, the highest percentage of technologies 53.45, 53.09, and 25.64in ideas, perception, and skills, respectively perceived by the agribusiness personnel in spices and pulse 50.93, 48.86, and 20.14,vegetables 48.29, 47.36, 21.50, and cereal crops 41.59, 36.45, and 23.41, respectively. There were found significant variations in respect of ideas/perception, and skills of improved technological knowledge. This results also supported by [14] and [36] as statement on the farmers' technological knowledge. Considering the total number of crops technological knowledge, the maximum improved technologies (47.57) were perceived by the agribusiness personnel ideas followed by perception $(45.28 \%)$, while the minimum technologies $(22.41 \%)$ in skills of technology category but found no significant differences between ideas and perception in respect of agribusiness personnel knowledge.

\section{Post-harvest Activities}

The results depicted in (Table 4) found significant variations in the perceptions of agribusiness personnel on NARS recognized technologies/activities regarding post-harvest activities viz. harvest index, accompanying pest at harvest and post-harvest processing available in the field of different crops. In case of cereal crops, the percent of known post-harvest activities ranged from 17.89-73.11,forvegetables/fruits cases13.14-67.00where the highest numbers of activities were observed in respect of harvest index and the lowest numbers of activities were observed in respect of accompanying pest at harvest. More or less similar trends observed in pulse 11.86-64.67 and spices 11.57-66.33 respectively. Sharp and significant variations were observed among three categories of post-harvest activities for harvest index, accompanying pest at harvest and post-harvest processing, respectively in respect of all type of crops. The research teams [3] and [33] also supported the results as stated in the farmers' post-harvest activities.

Table 4. Agribusiness personnel's perception of technological knowledge on pre and post-harvest management of agricultural pests and their economic impacts in Bangladesh

\begin{tabular}{|c|c|c|c|c|c|c|c|c|c|c|}
\hline \multirow{3}{*}{$\begin{array}{l}\text { Technological } \\
\text { Category }\end{array}$} & \multicolumn{10}{|c|}{ Crop Wise Technological Knowledge } \\
\hline & \multicolumn{2}{|c|}{ Cereal } & \multicolumn{2}{|c|}{ Vegetable/Fruit } & \multicolumn{2}{|c|}{ Pulse } & \multicolumn{2}{|c|}{ Spices } & \multicolumn{2}{|c|}{ Total } \\
\hline & $\begin{array}{c}\text { *NARS } \\
\text { Tech (No.) }\end{array}$ & $\begin{array}{c}\text { Response } \\
(\%)\end{array}$ & $\begin{array}{c}\text { *NARS } \\
\text { Tech (No.) }\end{array}$ & $\begin{array}{c}\text { Response } \\
(\%)\end{array}$ & $\begin{array}{c}\text { *NARS Tech } \\
\text { (No.) }\end{array}$ & $\begin{array}{c}\text { Response } \\
(\%)\end{array}$ & \begin{tabular}{|c|} 
*NARS \\
Tech (No.)
\end{tabular} & $\begin{array}{c}\text { Response } \\
(\%)\end{array}$ & $\begin{array}{c}\text { *NARS } \\
\text { Tech (No.) }\end{array}$ & $\begin{array}{c}\text { Response } \\
(\%)\end{array}$ \\
\hline \multicolumn{11}{|c|}{ 1. Technological Knowledge } \\
\hline Ideas & 22 & $\begin{array}{l}41.59 \\
(9.15)\end{array}$ & 28 & $\begin{array}{c}48.29 \\
(13.52)\end{array}$ & 14 & $\begin{array}{c}50.93 \\
(50.93)\end{array}$ & 11 & $\begin{array}{l}53.45 \\
(5.88)\end{array}$ & 75 & $\begin{array}{c}47.57 \\
(35.68)\end{array}$ \\
\hline Perception & 22 & $\begin{array}{l}36.45 \\
(8.02)\end{array}$ & 28 & $\begin{array}{c}47.36 \\
(13.26)\end{array}$ & 14 & $\begin{array}{l}48.86 \\
(6.84) \\
\end{array}$ & 11 & $\begin{array}{c}53.09 \\
(5.84))\end{array}$ & 75 & $\begin{array}{c}45.28 \\
(33.06)\end{array}$ \\
\hline Skills & 22 & $\begin{array}{l}23.41 \\
(5.15)\end{array}$ & 28 & $\begin{array}{l}21.50 \\
(6.02)\end{array}$ & 14 & $\begin{array}{l}20.14 \\
(2.82)\end{array}$ & 11 & $\begin{array}{l}25.64 \\
(2.82)\end{array}$ & 75 & $\begin{array}{c}22.41 \\
(16.81)\end{array}$ \\
\hline \multicolumn{11}{|c|}{ 2. Post Harvest Activities } \\
\hline Harvest Index & 9 & $\begin{array}{l}73.11 \\
(6.58) \\
\end{array}$ & 9 & $\begin{array}{l}67.00 \\
(6.03)\end{array}$ & 9 & $\begin{array}{l}64.67 \\
(5.82)\end{array}$ & 9 & $\begin{array}{l}66.33 \\
(5.97)\end{array}$ & 36 & $\begin{array}{c}67.78 \\
(24.40)\end{array}$ \\
\hline $\begin{array}{l}\text { Accompanying } \\
\text { pest at harvest }\end{array}$ & 9 & $\begin{array}{l}17.89 \\
(1.61)\end{array}$ & 7 & $\begin{array}{l}13.14 \\
(0.92)\end{array}$ & 7 & $\begin{array}{l}11.86 \\
(0.83)\end{array}$ & 7 & $\begin{array}{l}11.57 \\
(0.81)\end{array}$ & 30 & $\begin{array}{l}13.90 \\
(4.17)\end{array}$ \\
\hline $\begin{array}{c}\text { Post-harvest } \\
\text { Processing }\end{array}$ & 12 & $\begin{array}{l}67.42 \\
(8.09)\end{array}$ & 6 & $\begin{array}{l}75.00 \\
(4.50)\end{array}$ & 3 & $\begin{array}{l}52.00 \\
(1.56)\end{array}$ & 3 & $\begin{array}{l}49.67 \\
(1.49)\end{array}$ & 24 & $\begin{array}{c}65.17 \\
(15.64)\end{array}$ \\
\hline
\end{tabular}

The number within the parenthesis indicates the number of technologies being responded by the farmer. * the number of NARS recognized available technologies 


\section{e) Technology-based Technological Knowledge for All Categories Respondents}

The technology based knowledge ideas, perception and skills of improved technologies. The data were collected on the above three categories of technological aspects for 4 major crops group and are given in the Table 5 .

\section{Ideas about Technology}

Four categories of respondent's viz. researcher, extensionist, farmer, and agribusiness personnel for different categories of crops found significant variations were observed in ideas about technology depicted in (Table 5), In case of researcher, the percent of ideas about technologies ranged from 55.89-70.69, where the highest number observed in post-harvest technology and lowest number observed in agribusiness technology. In case of Extensionist the highest percent (53.69) was observed in post-harvest technologies but lowest percent (35.83) was observed in pest management technologies but there is a significant variation among three categories of technologies. Similar trends were also observed for farmers and agribusiness personnel where highest percent 32.38 \& 56.56 was observed in post-harvest technologies but lowest $17.41 \& 29.27$ was observed in pest management technologies. But there was significant difference among three categories of technologies. This result supports by the statement of USAID-BARC report: Crop Loss and Waste Assessment, 1991 indicated that to increase the food supply in the 21 st Century, reducing post-harvest losses is likely to be a much cheaper and easier path than trying to increase yields by the same amount. In regards of respondent's ideas about technological knowledge, the highest percent technologies (64.18) perceived by researcher category in all categories of technologies, followed by agribusiness personnel (48.96) and extensionist (43.94) while minimum was by famer (25.14) respectively.

\section{Perception about Technology}

The perception about technology comprises perception about post-harvest, pest management and agribusiness technology. The data were collected on the above three categories for 4 types of respondents. The data depicted in (Table 5) found significant variations in perception about technology regarding four categories of respondent viz. researcher, extensionist, farmer, and agribusiness personnel of different crops. In respect of researcher perception about technological knowledge, the percent responses were 68.38, 65.98, and 55.89 where highest percent response perceived under post-harvest technology and lowest response perceived in agribusiness technology. But in case of extensionist, the highest response was perceived in postharvest technology (53.69) and lowest was in pest management technology. The similar trends were also observed for farmers and agribusiness personnel, where highest responses were perceived in post-harvest technology (32.38 \& 56.56) and lowest in pest management technology (17.41 \& 29.27).Similarly this result also support by the Report of USAID-BARC: Crop Loss and Waste Assessment, 1991.The results depicted in Table 5, in regards of the respondents wise distribution of the data shown that the Farmer's marked lowest average percent 24.47 and highest was in Researcher 63.05; in agribusiness personnel $(47.16 \%)$ and in extensionist $(44.15 \%)$ respectively.

\section{Skills about Technology}

The skill about technology comprises skills about post-harvest, pest management and agribusiness technology. Significant variations were observed in skills about technology on the NARS recognized technologies regarding four categories of respondent viz. researcher, extensionist, farmer, and agribusiness personnel of crops (Table-5). In case of researcher, the highest number of activities observed in post-harvest technology and the lowest observed in agribusiness technology. In case of extensionist the highest percent (50.56) was observed in post-harvest technologies but lowest percent (25.17) was observed in pest management technologies but there is significant variation among three categories of technologies. Similar trends were also observed for farmers and agribusiness personnel where the highest percent (52.63) was observed in post-harvest technologies but lowest percent (32.93) was observed in pest management technologies but there is significant difference among three categories of technologies except farmer. Similarly this result also support by the Report of USAID-BARC: Crop Loss and Waste Assessment, 1991. In regards of respondents skills about technological knowledge highest percent 61.90 were perceived by researcher in all categories of technologies, followed by agribusiness personnel (49.04), and extensionist (39.03) and minimum percent was by famer (16.82) respectively. 
Table 5. Perception of technology-based technological knowledge for all categories respondents on pre and post-harvest management of agricultural pests and their economic impacts in Bangladesh

\begin{tabular}{|c|c|c|c|c|c|c|c|c|c|c|}
\hline \multirow{3}{*}{$\begin{array}{l}\text { Technological } \\
\text { Category }\end{array}$} & \multicolumn{10}{|c|}{ Categories of Respondents } \\
\hline & \multicolumn{2}{|c|}{ Researcher } & \multicolumn{2}{|c|}{ Extensionist } & \multicolumn{2}{|c|}{ Farmer } & \multicolumn{2}{|c|}{ Agribusiness } & \multicolumn{2}{|c|}{ Total } \\
\hline & $\begin{array}{c}\text { *NARS Tech } \\
\text { (No.) }\end{array}$ & \begin{tabular}{|c|} 
Response \\
$(\%)$
\end{tabular} & $\begin{array}{c}\text { *NARS } \\
\text { Tech (No.) }\end{array}$ & \begin{tabular}{|c|} 
Response \\
$(\%)$
\end{tabular} & $\begin{array}{c}\text { *NARS } \\
\text { Tech (No.) }\end{array}$ & \begin{tabular}{|c|} 
Response \\
$(\%)$
\end{tabular} & \begin{tabular}{c|} 
*NARS \\
Tech (No.)
\end{tabular} & \begin{tabular}{|c|}
$\begin{array}{c}\text { Response } \\
(\%)\end{array}$ \\
\end{tabular} & $\begin{array}{c}\text { *NARS } \\
\text { Tech (No.) }\end{array}$ & \begin{tabular}{|c|} 
Response \\
$(\%)$
\end{tabular} \\
\hline \multicolumn{11}{|c|}{ 1. Ideas about Technology } \\
\hline $\begin{array}{c}\text { Ideas about NARS } \\
\text { Post-harvest } \\
\text { technology }\end{array}$ & 8 & $\begin{array}{l}70.69 \\
(5.65) \\
\end{array}$ & 8 & $\begin{array}{l}53.69 \\
(4.29)\end{array}$ & 8 & $\begin{array}{l}32.38 \\
(2.59)\end{array}$ & 8 & $\begin{array}{l}56.56 \\
(4.52)\end{array}$ & 32 & $\begin{array}{l}52.47 \\
(4.26)\end{array}$ \\
\hline $\begin{array}{c}\text { Ideas about Pest } \\
\text { Management (IPM) } \\
\text { technology }\end{array}$ & 16 & $\begin{array}{c}65.98 \\
(10.56)\end{array}$ & 16 & $\begin{array}{l}35.83 \\
(5.73)\end{array}$ & 16 & $\begin{array}{l}17.41 \\
(2.79)\end{array}$ & 16 & $\begin{array}{l}29.27 \\
(4.68)\end{array}$ & 64 & $\begin{array}{l}37.12 \\
(5.94) \\
\end{array}$ \\
\hline $\begin{array}{l}\text { Ideas about } \\
\text { agribusiness } \\
\text { technology }\end{array}$ & 12 & $\begin{array}{l}55.89 \\
(6.71) \\
\end{array}$ & 12 & $\begin{array}{l}42.32 \\
(5.08)\end{array}$ & 12 & $\begin{array}{l}25.63 \\
(3.08)\end{array}$ & 12 & $\begin{array}{l}61.05 \\
(7.33) \\
\end{array}$ & 48 & $\begin{array}{l}46.22 \\
(5.55)\end{array}$ \\
\hline Average Total & 12 & 64.18 & 12 & 43.94 & 12 & 25.14 & 12 & 48.96 & & \\
\hline \multicolumn{11}{|c|}{ 2. Perception about technology } \\
\hline $\begin{array}{c}\text { Perception about } \\
\text { NARS Post-harvest } \\
\text { technology }\end{array}$ & 8 & $\begin{array}{l}68.38 \\
(5.47)\end{array}$ & 8 & $\begin{array}{l}53.31 \\
(4.27)\end{array}$ & 8 & $\begin{array}{l}32.25 \\
(2.58)\end{array}$ & 8 & $\begin{array}{l}52.19 \\
(4.18)\end{array}$ & 32 & $\begin{array}{l}51.53 \\
(4.12)\end{array}$ \\
\hline $\begin{array}{l}\text { Perception about Pest } \\
\text { Management } \\
\text { technology }\end{array}$ & 16 & $\begin{array}{c}65.98 \\
(1056)\end{array}$ & 16 & $\begin{array}{l}37.46 \\
(5.99)\end{array}$ & 16 & $\begin{array}{l}16.54 \\
(2.65)\end{array}$ & 16 & $\begin{array}{l}25.61 \\
(4.10)\end{array}$ & 64 & $\begin{array}{l}36.40 \\
(5.82)\end{array}$ \\
\hline $\begin{array}{l}\text { Perception about } \\
\text { agribusiness } \\
\text { technology } \\
\end{array}$ & 12 & $\begin{array}{l}54.79 \\
(6.57)\end{array}$ & 12 & $\begin{array}{l}41.68 \\
(5.00)\end{array}$ & 12 & $\begin{array}{l}24.63 \\
(2.96)\end{array}$ & 12 & $\begin{array}{l}63.68 \\
(7.64)\end{array}$ & 48 & $\begin{array}{l}46.20 \\
(5.54)\end{array}$ \\
\hline Average total & 12 & 63.05 & 12 & 44.15 & 12 & 24.47 & 12 & 47.16 & & \\
\hline \multicolumn{11}{|c|}{ 3. Skills about technology } \\
\hline $\begin{array}{c}\text { Skills about NARS } \\
\text { Post-harvest } \\
\text { technology }\end{array}$ & 8 & $\begin{array}{l}65.31 \\
(5.23)\end{array}$ & 8 & $\begin{array}{l}50.56 \\
(4.05)\end{array}$ & 8 & $\begin{array}{l}17.06 \\
(1.37)\end{array}$ & 8 & $\begin{array}{l}52.63 \\
(4.21)\end{array}$ & 32 & $\begin{array}{l}46.39 \\
(3.71)\end{array}$ \\
\hline $\begin{array}{c}\text { Skills about Pest } \\
\text { Management } \\
\text { technology }\end{array}$ & 16 & $\begin{array}{c}65.98 \\
(10.56) \\
\end{array}$ & 16 & $\begin{array}{l}25.17 \\
(4.03)\end{array}$ & 16 & $\begin{array}{l}14.10 \\
(2.26)\end{array}$ & 16 & $\begin{array}{l}32.93 \\
(5.27)\end{array}$ & 64 & $\begin{array}{l}34.54 \\
(5.53)\end{array}$ \\
\hline $\begin{array}{c}\text { Skills about } \\
\text { agribusiness } \\
\text { technology }\end{array}$ & 12 & $\begin{array}{l}54.42 \\
(6.53)\end{array}$ & 12 & $\begin{array}{l}41.37 \\
(4.96)\end{array}$ & 12 & $\begin{array}{l}19.32 \\
(2.32)\end{array}$ & 12 & $\begin{array}{l}61.58 \\
(5.30)\end{array}$ & 48 & $\begin{array}{l}44.17 \\
(5.30)\end{array}$ \\
\hline Average total & 12 & 61.90 & 12 & 39.03 & 12 & 16.82 & 12 & 49.04 & & \\
\hline
\end{tabular}

The number within the parenthesis indicates the number of technologies being responded by the farmer. * the number of NARS recognized available technologies

\section{F) Post-harvest Activities-based Technological Knowledge for All Categories Respondents}

The post-harvest activities based on harvest index, pests accompanying at harvest, and post-harvest processing. The data were collected on the above three categories of technological aspects for four major crops group and are given in Table 6.

\section{Harvest Index}

The harvest-index consisted of ideas of maturity symptom, perception and skills of maturity symptom of crops. The data were collected on the above three categories of technological aspects for 4 types of respondents and are given in the Table 6.

The results depicted in (Table 6) found no significant variations in the perceptions of post-harvest activities viz. ideas, perception and skills of crops. In case of researcher, the percent of post-harvest activities ranged from 62.75-63.83, where the highest numbers observed in ideas of maturity symptom with minimal difference with perception and skills. In case of extensionist, the percent of known post-harvest activities is 52.75 in all three stage of technological knowledge. In respect of farmers, the percent knowledge of post-harvest activities ranged from 37.92-42.92 where highest percent perceived in ideas of maturity symptom and lowest percent (37.92) in skills of maturity symptom. The similar trends were in agribusiness where highest percent (50.42) perceived in ideas of maturity symptom of crops and lowest percent (44.47) in skills of maturity symptom of crops. Sharp variations were also observed among these two categories of respondents.

The researcher team [1] stated that Post-harvest activities in Bangladesh are traditional and labour intensive. The main activities are manual harvesting, manual threshing, animal or mechanical treading, sun drying, 
traditional parboiling and milling in huller mills or traditional devices. The owners of automatic rice mills can take out loans to run the mills. Some action program is suggested for the adoption of appropriate post-harvest technology and the improvement of rice processing and marketing. The respondent's wise distribution of the data shown that the researcher marked highest 63.11 followed by extensionist (52.75) Agribusiness person (46.52) and lowest in case of Farmer's 41.25 under all three categories technologies.

\section{Post-harvest Processing}

The data were collected on the above three categories for 4 types of respondents. The data depicted in (Table 6) found significant variations in post-harvest processing regarding four categories of respondent of crops. In respect of researcher perception about technological knowledge, the percent responses were $81.38,81.38$, and 69.63 where highest percent response perceived under ideas and perception technology and lowest response perceived in skills category of the technology. This result supported by [21] statement that food resources often go to waste because of poor post-harvest handling, inadequate storage facilities and a lack of appropriate food-processing technology in villages. In addition [10] found the problems still facing food processing companies in the Korea Republic, particularly small-scale enterprises run by farmers or their cooperatives, are discussed. The Korea Republic government has been actively promoting food processing in rural areas, as a way of stabilizing prices for farm produce, providing job opportunities and raising farm incomes. The similar trends also observed in extensionist, farmers and agribusiness personnel, where highest responses were perceived in ideas of the technology (57.88,
$41.25, \& 61.50)$ and lowest in skills of the technology $(46.13,26.63, \& 49.00)$ respectively.

\section{Storage Environment}

The principle objective in any storage system is to maintain the stored commodity in good condition, so as to avoid deterioration both in quality and quantity. The storage environment comprises Ideas, Perception and Skills of storage environment post-harvest technologies/activities. The data were collected on the above three categories for 4 types of respondents. The data depicted in (Table 6) found significant variations in post-harvest storage environment on the NARS recognized technologies regarding four categories of respondent viz. researcher, extensionist, farmer, and agribusiness personnel handled in different crops. In respect of researcher perception about Ideas, the percent were $91.38,88.80$, and 69.40 where highest percent perceived under ideas and perception and lowest in skills. According to the scientists, the farmers store more than $65 \%$ of the total rice produces till the next season for their food, feed and seed purposes. The research group [30] reported that about 5-8\% of rice was stored for seed. During the storage condition of ambient temperature, rice is being damaged by a number of agents, such as insects, rodents, fungi, mites, birds and moisture [30]. The similar trends also observed for extensionist, farmers and agribusiness personnel, where highest responses were perceived in ideas of the technology $(80.75,53.00, \& 84.25)$ and lowest in skills $51.50,17.90, \& 53.50$ respectively. According to respondent's wise distribution of the data shown (Table-6) that the Farmer's marked lowest average percent24.99 and highest percent was in Researcher83.16extensionist (70.32) and agribusiness personnel (70.02) respectively.

Table 6. Perception of post-harvest activities based technological knowledge for all categories respondents on pre and post-harvest management of agricultural pests and their economic impacts in Bangladesh

\begin{tabular}{|c|c|c|c|c|c|c|c|c|c|c|}
\hline \multirow{3}{*}{$\begin{array}{c}\text { Technological } \\
\text { Category }\end{array}$} & \multicolumn{10}{|c|}{ Categories of Respondents } \\
\hline & \multicolumn{2}{|c|}{ Researcher } & \multicolumn{2}{|c|}{ Extensionist } & \multicolumn{2}{|c|}{ Farmer } & \multicolumn{2}{|c|}{ Agribusiness } & \multicolumn{2}{|c|}{ Total } \\
\hline & $\begin{array}{c}\text { *NARS } \\
\text { Tech (No.) }\end{array}$ & $\begin{array}{c}\text { Response } \\
(\%)\end{array}$ & $\begin{array}{c}\text { *NARS Tech } \\
\text { (No.) }\end{array}$ & $\begin{array}{c}\text { Response } \\
(\%)\end{array}$ & $\begin{array}{c}\text { *NARS } \\
\text { Tech (No.) }\end{array}$ & $\begin{array}{c}\text { Response } \\
(\%)\end{array}$ & \begin{tabular}{|c|} 
*NARS \\
Tech (No.)
\end{tabular} & \begin{tabular}{|c|} 
Response \\
$(\%)$
\end{tabular} & $\begin{array}{c}* \text { NARS } \\
\text { Tech (No.) }\end{array}$ & $\begin{array}{c}\text { Response } \\
(\%)\end{array}$ \\
\hline \multicolumn{11}{|c|}{ 1. Harvest Index } \\
\hline $\begin{array}{c}\text { Ideas of Maturity } \\
\text { Symptom }\end{array}$ & 12 & $\begin{array}{l}63.83 \\
(7.66) \\
\end{array}$ & 12 & $\begin{array}{l}52.75 \\
(6.33) \\
\end{array}$ & 12 & $\begin{array}{l}42.92 \\
(5.15)\end{array}$ & 12 & $\begin{array}{l}50.42 \\
(6.05) \\
\end{array}$ & 48 & $\begin{array}{c}52.48 \\
(25.19)\end{array}$ \\
\hline $\begin{array}{c}\text { Skills of Maturity } \\
\text { symptom }\end{array}$ & 12 & $\begin{array}{l}62.75 \\
(7.53) \\
\end{array}$ & 12 & $\begin{array}{l}52.75 \\
(6.33) \\
\end{array}$ & 12 & $\begin{array}{l}37.92 \\
(4.55) \\
\end{array}$ & 12 & $\begin{array}{l}44.47 \\
(5.36) \\
\end{array}$ & 48 & $\begin{array}{c}49.52 \\
(23.77) \\
\end{array}$ \\
\hline Average Total & 12 & 63.11 & 12 & 52.75 & 12 & 41.25 & 12 & 46.52 & - & - \\
\hline \multicolumn{11}{|c|}{ 2. Post-harvest Processing } \\
\hline Ideas & 8 & $\begin{array}{l}81.38 \\
(6.51)\end{array}$ & 8 & $\begin{array}{l}57.88 \\
(4.63) \\
\end{array}$ & 8 & $\begin{array}{l}41.25 \\
(3.30)\end{array}$ & 8 & $\begin{array}{l}61.50 \\
(4.92)\end{array}$ & 32 & $\begin{array}{c}60.50 \\
(19.36)\end{array}$ \\
\hline Perception & 8 & $\begin{array}{l}81.38 \\
(6.51) \\
\end{array}$ & 8 & $\begin{array}{l}57.88 \\
(4.63) \\
\end{array}$ & 8 & $\begin{array}{l}39.38 \\
(3.15) \\
\end{array}$ & 8 & $\begin{array}{l}53.13 \\
(4.25) \\
\end{array}$ & 32 & $\begin{array}{c}57.94 \\
(18.54) \\
\end{array}$ \\
\hline Skills & 8 & $\begin{array}{l}69.63 \\
(5.57) \\
\end{array}$ & 8 & $\begin{array}{l}46.13 \\
(3.69) \\
\end{array}$ & 8 & $\begin{array}{l}26.63 \\
(2.13) \\
\end{array}$ & 8 & $\begin{array}{l}49.00 \\
(3.92) \\
\end{array}$ & 32 & $\begin{array}{c}47.84 \\
(15.31) \\
\end{array}$ \\
\hline Average Total & 8 & 77.46 & 8 & 53.93 & 8 & 35.75 & 8 & 54.54 & - & - \\
\hline
\end{tabular}

The number within the parenthesis indicates the number of technologies being responded by the farmer. * the number of NARS recognized available technologies 


\section{Future Strategies Need To Be Strengthened on Post Harvest Management}

- Priority must focus on postharvest sector to ensure food security, alleviate poverty, increase employment opportunities and promote national and foreign investment.

- A platform of networks should be created among growers, entrepreneurs, technology providers and consumers in order to provide the impetus required for accelerated investment in the sector.

- Post-harvest research and development programs must be established at national level to maintain quality standard for food safety, security and international trade.

- Long- and short-term human resource development program should be undertaken at all levels.

- Roads, storage facilities and the legislation required to maintain for proper functioning of post-harvest infrastructure.

- Financial and technical support for the development of packaging industries is required.

- Sharing of information through electronic and print media, training, meetings and conferences at national and international level.

\section{Conclusions}

The government of Bangladesh has taken the initiative to modernize the agricultural sector in light of WTO rules and SAPTA and other international treaties for developing profitable and sustainable agricultural production systems, reducing imports of agricultural produce and products, increasing exports and facilitating the development of agro-processing industries. There are about more than 300 NARS recommended technologies for agricultural sector including pre- and post-harvest management system in Bangladesh for this need based initiatives but only a few of them are being practiced at field level. Efforts must be made to strengthen the postharvest sector through intensive investment in research and development. Post-harvest management eliminates undesirable elements and improves product appearance, as well as ensuring product quality with established standards. The economy of the country will be strengthened through quality improvement, increased production, increased market share and greater foreign exchange earnings derived from increased export of fresh and processed fruits and vegetables. There is a big knowledge gap among researchers and other respondent. Considering all technological categories, perception of researchers on NARS recommended Technological Knowledge is much higher than farmers, extensionist and agribusiness personnel. Most of the respondents are very much aware about the rice based technologies rather than other crops. There is huge scope to minimize postharvest (harvesting, transport, threshing and cleaning) losses by using modern technologies and mechanization. People's awareness on step wise post-harvest losses is decreasing following various development activities are going on in this regard. Farmers are now adopting different techniques.

\section{REFERENCES}

[1] Ahmed, M.S. 2003. Interim Report from 15 September to 15 December 2003 as National Consultant for Post-Harvest and Agribusiness Specialist for Northwest Crop Diversification Project, Department of Agricultural Extension (DAE), Khamarbari, Dhaka, Bangladesh. 15p.

[2] Ahaduzzaman, S. M. 1999. Adoption of Modern T. Aman Technologies among the Rice Growers in Sadar Thana of Rangpur District. M.S. (Ag. Ext. Ed.) Thesis, Department of Agricultural Extension Education, Bangladesh Agricultural University, Mymensingh.

[3] Akhter, A., Mazed, M.A. and Ahmed, A. 1996: Improving the rice post-harvest technology in Bangladesh. Bangladesh Rice Research Institute, Gazipur 1701, Bangladesh.

[4] Amiruzzaman, N. 1990. Postharvest handling and processing of fruits and vegetables. In 'Kitchen Gardening and Homestead Productive Activities'. CIRDAP Action Research Series No. 11. p.22.

[5] Azad, M.I. 2001. Reduction of Postharvest Losses and Extension of Shelf Life of Mango. PhD Thesis, Department of Horticulture, Bangladesh Agricultural University, Mymensingh. p. 244

[6] Azad,.M..J; Ali, S.M and Islam, R.M. 2013. FARMERS' KNOWLEDGE ON POSTHARVEST PRACTICES OF VEGETABLES. Sher-e-Bangla Agricultural University, Dhaka, MS Thesis pp-13

[7] Azu J. 2002. Post Harvest loss reduction OICI Tamales quick interventions for reducing food insecurity, Ghana, OICI, International

[8] BBS. 2013. Bangladesh Bureau of Statistics. Statistics Division, Ministry of Planning, Government of the People's Republic of Bangladesh

[9] BBS. 2009. Monthly Statistical Bulletin (April). Bangladesh Bureau of Statistics. Statistics Division, Ministry of Planning, Government of the People's Republic of Bangladesh, p. 67.

[10] Choi, JU., Park, HD. 1995. The promotion of food processing by farmers in Korea. Department of Food Science and Technology, Kyungpook National University, Korea Republic.

Extension-Bulletin-ASPAC,-Food-and-Fertilizer-Technolo gy-Center. No. 412, 6 pp.; 6 ref.

[11] CIPHET. 2009. Central Institute of Postharvest Engineering and Technology, Ludiana Newsletter. April 2009. Volume 4, Number 4.

[12] Ehlenfeldt, M.K., and Hepp, R.F. 2002. Postharvest research 
and technology in Vaccinium. Proceedings of the Seventh International Symposium on Vaccinium Culture, Termas de Chillan, Chile. Pp. 31-38.

[13] FAO 2009. Course on agribusiness management for producers' associations. Module 4 - Post- harvest and marketing. Santacoloma P, Roettger A, Tartanac F (eds) Training materials for agricultural management, marketing and finance, Vol. 8. Food and Agriculture Organization of the United Nations, Rome

[14] Goletti, F. and Wolff, C. 1999.The impact of postharvest research. Market and Structural Studies Division, International Food Policy Research Institute, USA.

[15] Hossain, M.I. 2001. Knowledge Gained by the Participating Farmers under Crop Cultivation Programme of CARE in a Selected Area of Mymensingh District. M.S. (Ag. Ext. Ed). Thesis, of Agricultural Extension Education, Bangladesh Agricultural University, Mymensingh.

[16] Hossain, M.I. 1993: Assessment of post-harvest technology of khesari and lentil in selected areas of Bangladesh. Agricultural Economics Division, Bangladesh Agricultural Research Institute, Joydebpur, Bangladesh. Economic Affairs Calcutta. 38(3): 173-179.

[17] Hodges, R.J., Buzby J.C., and BennettB.,2011, Postharvest losses and waste in developed and less developed countries: opportunities to improve resource use, Journal of Agricultural Science, 149, 37-45

[18] Islam, M.N. 2008. Knowledge on Vegetables Production Activities by Woman Members in Homestead Area under World Vision Project. M.S. (AEIS). Thesis, Department of Agricultural Extension and Information System, Sher-e-Bangla Agricultural University, Dhaka.

[19] JAVED, M.A; Ali,S.M and Islam,M.R. 2013. Farmers knowledge on postharvest practices of vegetables. Sher-e-Bangla Agricultural University, MS Thesis PP.13.

[20] Kader A.A. 1992 Postharvest biology and technology: an overview. In: Kader AA (ed) Postharvest technology of horticultural crops. UC Publication No. 3311. University of California, Division of Agriculture and Natural Resources, Oakland, pp 15-20.

[21] Kaakeh, W. and Hogmire, H.W. 1991.Biology and control of green peach aphid, M. persicae (sulzer) on peach in West Virginia, USA. Journal of Plant Protection. 9(2):124-128.

[22] Manjunatha,B.N., Lakshminarayan,M.T. and Anand, T.N. 1998.Variables influencing farmers' aspirations for new post-harvest technologies in groundnut, Current-Research, University of Agricultural Sciences Bangalore. Pp 184-185

[23] Monselise, S.P., and Goren, R. 1987. Preharvest growing conditions and postharvest behavior of subtropical and temperate-zone fruits. HortScience, 22, 1185-1189

[24] Mondal, M.F., M.A. Rahman, and M.A.J. Pramanik. 1995. Effects of different postharvest treatments on physico-chemical changes and shelf life of mango. Bangladesh Horticulture, 23(1\&2):1-5.
[25] NAS (National Academy of Science). 1978. Postharvest food losses in developing countries. Washington DC

[26] Muntad, A.(2009. Principal losses, http//:www.fao/docrep/T00731/..on 01.12.2012 (Manan)

[27] Okezie, B.O. 1998. World food security: the role of postharvest technology. Food Technology, 52: 64-69.

[28] Paull, R.E. 1993. Tropical fruit physiology and storage potential. In: Proceedings of an International Conference on Postharvest Handling of Tropical Fruits (Camp, B.R.,Highley, E. and Johnson, G.I., Eds.). Australian Centre for International Agricultural Research (ACIAR Proceedings No. 50), Canberra. pp. 198-204

[29] Pedreschi, R., Lurie, S., Hertog, M., Nicolaï, B., Mes, J. and Woltering, E. (2013), Post-harvest proteomics and food security. Proteomics, 13: 1772-1783. doi:10.1002/pmic.201200387

[30] Prakas, A, and J. Rao. 1983. Insect pests and their management in rice storage in India, presented in National Symposium on Maximizing and Stabilizing of yields on rain fed rice production system held at CSRRI, Cuttack (India) on Feb. 23-25, 1983.

[31] Prakash, A, J. Rao, I. C. Pasalu and Mathur, K. C. 1987. Rice Storage and insect pest management. B. R. Publishing Corporation. Delhi, pp.15-60.

[32] Quroshi, S.U., and Meah, M..B. 1991. Postharvest loss in mango owing to stem-end rot. International Journal of Tropical Agriculture, 9(2): 98-105

[33] Rahman, M.A., Miah, M.A.K., Akhter, Ahmed. And Ahmed, A. 1996: Status of rice processing technology in Bangladesh. Farm Machinery and Post-harvest Technology Division, Bangladesh Rice Research Institute, Gazipur 1701, Bangladesh. Agricultural Mechanization in Asia, Africa and Latin America. 27(1):46-50.

[34] Raj, A.S. and Knight, J.A.1977. Influence of Farm Practices Attributes on Innovation-decision process. Indian Journal of Extension Education. 13(3\&4):1-5.

[35] Srivastava, NSL. 1993. Potential of income and employment generation through use of agricultural engineering technology in production agriculture and post harvest operations. Central Institute of Agricultural Engineering, India .Agricultural-Engineering-Today. Pp. 17-26; 5 ref.

[36] Waddington, S., and Kunjeku.,P. 1993. Current technology and research needed for rain fed cereal production in drought prone environments of southern Africa. SADC-L\&WMRP workshop paper. Pp. C21-33; 28 ref.

[37] Wills, R., B. Mc Glasson, Graham D. and Joyce, D. 2004. Postharvest: Introduction to the physiology and handling Fruits, Vegetables and Ornamentals (4th Edition).University of New South Wales Press Ltd., Sydney 2052, Australia, 262p.

[38] World Bank 2005b- "Revitalizing the Agricultural Technological System in Bangladesh" Bangladesh Development Series Paperno.7, World Bank Dhaka 